Acta vet. scand. 1989, 30, 103-105.

Brıef Communication

\title{
Plasminogen Activation in the Bovine Udder
}

Plasmin is a serin protease with a broad substrate specificity which might cause disintegration of basal membranes, epithelium and surrounding matrix. Plasmin might also elıcit degradation of tissue (Mullıns \& Rohrlich 1983).

Plasmin is formed by proteolytic activation of the inactive precursor plasminogen. This conversion is carried out by specific plasminogen activators (Saksela 1985), e.g. t1ssue type activator in blood and blood vessels, or urokinase, which seems to be the major type in urine, kidney and other tissue (Wiman \& Collen 1978) inducing degradation of tissue. Activators can be synthesized by e.g. stimulated macrophages (Saksela et al. 1985) and epithelial cells (Electricwala \& Atkınson 1985).

In bovine milk plasmin is the predominant proteolytic enzyme (Elgel et al. 1979, Schaar \& Funke 1986), however present mostly as the proenzyme, plasminogen. During udder inflammation plasminogen is activated (Schaar \& Funke 1986). The aim of this study was to investigate if plasmin could affect the tissue of the udder.

Five lactating cows were infused through the teat canal in 1 udder quarter each with the plasminogen activator urokinase, 200,000 IU in isotonic lactose solution. Isotonic lactose solution was infused in another quarter of each cow. At the time of infusion 1 of the urokinase treated quarters was shown to be previously infected with Pseudomonas aeruginosa, and the control quarter of another cow with coagulase negative staphylococci. Milk samples were collected on the day of infusion and during the following 7 days.
The effect of urokinase activation of plasminogen on the udder tissue was measured by the mastitis parameters somatic cell count (SCC), concentration of $\mathrm{Na}^{+}$, bovine serum albumin (BSA), adenosine tri-phosphate (ATP) and N-acetyl- $\beta$-D-glucoseamidase (NAGase). The amount of plasmin was also assayed. SCC was performed using a Fossomatic counter or by light microscopy on glass slides. $\mathrm{Na}^{+}$-concentration was determined using ion-selective electrodes (Beckman system E2A). Concentration of BSA was calculated by radial immunodiffusion (Mancini technique). The amount of ATP was determined using the firefly luciferase assay (Emanuelson et al 1986). Enzyme activity of NAGase was determined by fluorimetry (Kltchen et al. 1978). The plasmin actıvity was calculated with a colorimetric enzyme assay (Schaar \& Funke 1986).

Infusion with urokinase resulted in activation of the plasminogen present in the milk within $4 \mathrm{~h}$ post infusion. The plasmin activity slowly returned to the pre-infusion level within 2-3 days. The plasminogen present in the control quarters was not activated except in the infected control quarter where the plasminogen was activated within $6 \mathrm{~h}$ post infusion. The plasmin activity was reduced to the pre-infusion level $15 \mathrm{~h}$ later.

The administration of urokinase rsulted in a three-fold increase in SCC within $6 \mathrm{~h}$ in 3 out of 5 quarters. Simultaneously increase in the amount of ATP and NAGase was observed. In the Pseudomonas infected quarter the values of all parameters were elevated. Tissue bovine mammary gland was taken from the slaughter house to further elecit 


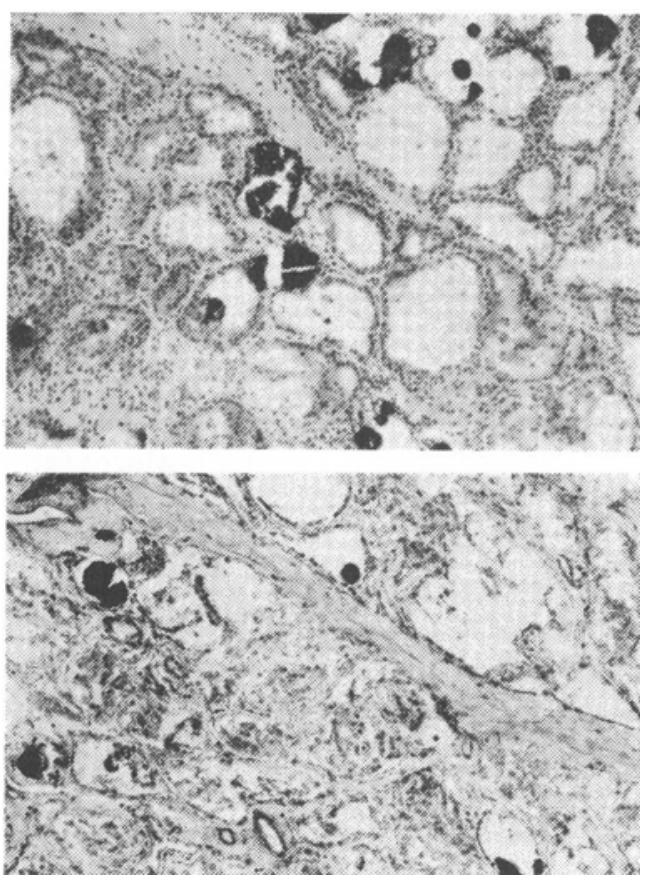

Figure 1. Effect of plasmin on the udder tissue. a) A control specimen of udder tissue, clearly showing alveoli $(\times 100)$.

b) A specimen of udder tissue treated for $6 \mathrm{~h}$ with plasmın, showing disıntegratıng of alveolar epithelial cells $(\times 100)$.

possible effects of plasmin on the tissue. The tissue samples were frozen and sectioned by a microtome. The specimens were incubated with plasmin at a concentration comparable to that of an inflamed udder quarter. Histopathological examinations of the udder tissue showed disintegration of the epithelial cells of the alveoli after incubation with plasmin (Fig. 1).

The results obtained demonstrate that plasminogen activated to plasmin in the udder, especially in infected quarters, can affect the udder tissue and thus maybe facilitate the mobilisation of udder defence factors e.g. by increasing the permeability of the udder epithelium.

\section{Acknowledgement}

The work was supported by the Swedish Council for Forestry and Agricultural Research.

\section{Lotta Hedkvist, Stefan Hoglund, Karın Persson and Olof Holmberg \\ Institute of Biochemistry, Biomedical Center, University of Uppsala and Departments of Obstetrics and Gynaecology and of Veterınary Microbıology, Section of Clinıcal Microbıology, Faculty of Veterınary Medicine, \\ Swedish University of Agricultural Sciences, Uppsala.}

\section{References}

Eigel WN, Hofmann CJ, Chibber BAK, Tomich $J M$, Keenan TW, Mertz ET Plasmin-mediated proteolysis of casein in bovine milk. Proc. Natl. Acad. Sci. (USA) 1979, 76, 2244-2248.

Electricwala A, Atkınson T Purification and properties of plasminogen activators from epithelial cells. Eur. J. Biochem. 1985, 147, 511516.

Emanuelson $U$, Olsson T, Holmberg $O$, Hageltorn $M$, Mattla $T$, Nelson L, Astrøm $G$ Comparison of some screening tests for detecting mastitis. J. Darry Res. 1986, 70, 880-887.

Kitchen BJ, Middleton $G$, Salmon $M$ Bovine mılk $\mathrm{N}$-acetyl-beta-D-glukoseamınidase and its significance in the detection of abnormal udder secretions. J. Dairy Res. 1978, 45, 15-20.

Mullins DB, Rohrlich ST The role of proteinases in cellular invasiveness. Biochim. B10phys. Acta 1983, 695, 177-214.

Saksela O, Hovl T, Vaherl A Urokinase-type plasminogen activator and its inhibitor secreted by cultured human monocyte-macrophages. J. Cell. Physiol. 1985, 122, 125-132.

Saksela $O$ : Plasmınogen activation and regulation of pericellular proteolysis. Biochim. Biophys. Acta 1985, 823, 35-65.

Schaar J, Funke $H^{\cdot}$ Effect of subclinical mastitis on milk plasminogen and plasmin compared 
with that on sodium anti-trypsin and $\mathrm{N}$-acetylbeta-D-glucoseamınidase. J. Dairy Res. 1986, $53,515-528$.
Wiman B, Collen $D$ On the kinetics of the reaction between human antiplasmin and plasmin. Europ. J. Biochem. 1978, 84, 573-578.

(Accepted January 20, 1989)

Reprints may be requested from: Olof Holmberg, Department of Veterınary Microbiology, Section of Clinical Microbıology, Swedish University of Agnicultural Sciences, P. O. Box 7073, S-750 07 Uppsala, Sweden. 
